\title{
African-German Cooperation towards Decolonising Higher Education: CERM-ESA Approaches and Lessons Learnt
}

\begin{abstract}
This paper looks into decolonisation as a guiding principle for North-South academic cooperation towards the United Nations 2030 Agenda on Sustainable Development adopted in 2015. The purpose of this article is to examine the German Academic Exchange Service (DAAD) funded African-German cooperation within the East and South African-German Centre of Excellence for Educational Research Methodologies and Management - CERM-ESA - and reflect on its conditions and its contributions to decolonising higher education. The article draws on relevant literature and reflects on CERM-ESA activities, face-to-face discussions with CERM-ESA faculty and students. The findings have practical implications for North-South cooperation partnerships aimed at decolonising higher education in Africa.
\end{abstract}

Keywords: North-South cooperation, decolonisation, Germany, Africa, German Academic Exchange Service (DAAD)

\section{Zusammenfassung}

Der vorliegende Artikel nutzt das Konzept der Dekolonialisierung als Leitlinie und Orientierungsrahmen für Nord-Süd Hochschulkooperationen, die einen Beitrag zu den nachhaltigen Entwicklungszielen der Vereinten Nationen (Sustainable Development Goals) leisten wollen. Dabei wird die Dekolonialisierung von Hochschulen, insbesondere in Afrika, als notwendige Voraussetzung für die Demokratisierung der Wissensproduktion sowie für die gesellschaftliche Relevanz von Wissenschaft in afrikanischen Kontexten diskutiert. Neben relevanter Literatur bezieht sich der Beitrag praxisnah auf Aktivitäten, Diskussionen und Entwicklungen des vom Deutschen Akademischen Austauschdienstes (DAAD) geförderten Projekts Ost- und Südafrikanisch-Deutsches Fachzentrum für Bildungsforschung und Bildungsmanagement - CERM-ESA der letzten fünf Jahre. Das Ziel dieses Artikels ist es, die Bedingungen und Beiträge des CERM-ESA Projekts zur Dekolonialisierung zu reflektieren. Die Ergebnisse dieser Reflektion liefern praktische Hinweise sowie Anlässe zum Überdenken für dieses und ähnliche Nord-Süd Hochschulkooperationsprojekte.
Schlüsselworte: Nord-Süd Bildungskooperation, afrikanisch-deutsche Hochschulpartnerschaft, Dekolonialisierung, Deutscher Akademischer Austauschdienst (DAAD)

\section{Introduction}

The notion of countries in the global North and the global South frame nations as either being rich, developed countries or poorer developing countries in need of assistance. Though this categorisation makes little geographical sense, the differences between nations in the global North and in the global South are clear in the socioeconomic and political spheres. However, there are also implicit and generally less well recognised psychosocial and experience-based inequalities rooted in the history of colonisation, racism and the struggle for liberation and decolonisation (Barongo-Muweke, 2016). These issues pervade most academic institutions in the global South and are evidenced by the often severe lack of material resources and equipment, very high student/staff ratios, high student numbers, low throughput rates, poor study environments for students, inadequate working conditions for the academic staff and low research outputs (Addo, 2010; Aina, 2010). At the same time, educational institutions, schooling and concepts of formal education in East and South Africa still largely rely on inherited models created in Europe and imposed by the former colonisers (Ordorika, 2017). Odora Hoppers (2002) points out that even the social construction of the reality of people in Africa is largely being defined not in Africa but elsewhere and Brock-Utne (2017) stresses that foreign (colonial) languages still dominate as languages of instruction in secondary and tertiary education institutions in East and South Africa. As such, if African universities are to position themselves as locally and nationally relevant institutions and equal players in the global arena, they need to change their mode of knowledge production, content and nature of knowledge systems and seek partnerships that help pursue the needed change (Aina, 2010).

The East and South African-German Centre of Excellence for Educational Research Methodologies and Management (CERM-ESA), which is at the centre of the following discussion, has attempted to position itself and operate within 
the underpinning structural and institutional inequalities resulting from the history of colonialism and current economic and political power relations between the North and the South. Similarly, it has attempted to respond to the call to decolonise education and educational institutions in order to make education meaningful and serve local communities, rather than inadvertently reproduce the social, political, economic and cultural inequalities.

\section{CERM-ESA background and objectives}

CERM-ESA is one of eleven Centres of African Excellence funded by the German Academic Exchange Service (DAAD) with funds from the German Federal Foreign Office (AA) at different Universities across Sub-Saharan Africa. Besides Moi University, CERM-ESA project partners are the University of Oldenburg, the Nelson Mandela University in Port Elizabeth, the University of Dar es Salaam and the Uganda Management Institute in Kampala. The physical Centre of CERM-ESA was launched in 2015 at Moi University, Eldoret, Kenya.

The objective of the overall DAAD funded Centre of African Excellence programme is spelled out on its website: "By establishing Centres of Excellence at leading African universities, the DAAD aims to create modern educational capacities of supra-regional influence. The improvements in the educational quality and the greater research capacity available at these world-class hubs will enable the next generation of leaders to acquire training in line with international standards. The goal for each centre is to strive to develop its own impact on the region and beyond" (African Excellence: Fachzentren, n.d.).

The impacts expected by these Centres of African Excellence are framed by the United Nation's Sustainable Development Goals (SDGs) and all project activities fall under the monitoring used for development cooperation projects funded by the German government. Within this framework, CERM-ESA is particularly oriented towards SDG 4: quality education, as well as the African Union's Agenda 2063 with its Continental Education Strategy for Africa (African Union Commission, 2016).

During the first funding phase (2014-2018), CERMESA's focus was on three programme pillars: 1) the academic programme, 2) the capacity building programme and 3) the research programme. A fourth pillar focusing on teacher professional development was added to CERM-ESA's programmes for the second funding phase (2019-2023). Unlike many similar projects at universities, this programme is fully funded and the German-African Centres enjoy relative freedom in their choice of subject area and activities. Despite the original call, CERM-ESA was able to convince the funder to include more than one African partner institution in order to create a South-South-North network instead of bilateral North-South collaboration. CERM-ESA adopted a conceptual framework using theories of internationalisation and engagement of higher education institutions (Möllendorff, Kurgat \& Speck, 2017) and set out with the following objectives:

- Advance and expand excellent and innovative educational research on methodologies, instruction and management strategies for African contexts (Research Programme: e.g. collaborative supervision of theses, research workshops and joint international research projects);
- Teach and train future educational leaders in terms of research methodologies, innovative management solutions and instruction techniques rooted in and for African contexts on Master's and PhD level (Academic Programme: e.g. postgraduate scholarships, annual research schools, master's degree programme, collaborative teaching);

- Advance capacity building and professional development in academia and management of the participating universities for sustainable institution building and for teachers and school principals to improve education and leadership in schools (Capacity Building Programme: short learning programmes, teachers' and principals' in-service training days, workshops).

What has been an important evolution of the CERM-ESA partnership over the past four years has not only been a frank recognition of the explicit and implicit challenges of higher education institutions in the South, but also the acknowledgement that a shared understanding of what is meant by decolonisation is required if partners are to consensually frame cooperative objectives and practices. The needs of higher education institutions in the South as understood by the initiators of the project were explicit in the funding proposal. However, a shared understanding of decolonisation and its use as a guiding principle for academic cooperation only emerged and became clearer as individuals in the partnership engaged authentically with one another in ways that enabled real change. In order to explain the processes of authentic engagement it would be salient to examine more general notions of what is meant by decolonisation.

\section{Excursus: Decolonisation}

Issues around decolonisation or Africanisation are not new and are not uncontested. Initially, resistance to colonialism from nationalist movements demanded radical restructuring of the power relations between the colonisers and their colonies (Horowitz, 1970; Goldberg, 1986). As such, what many have most often in mind when they think of decolonisation are the African postcolonial experiments in nation-building projects that took place in many newly independent African countries in the 1960s and 1970s (Mbembe, 2016). Decolonisation meant the dismantling or reorganisation of systems and structures set in place during the period of colonisation. Explicitly, it was seen as the process in which colonies previously controlled by imperialist systems gradually became politically independent. However, it soon became apparent that some elitist and exclusionist tendencies in the inherited models of colonial higher education institutions were not sufficiently addressed in the decolonisation and reform processes. It also became apparent that decolonisation had more far-reaching consequences and that education has a central role to play. From a higher education perspective, and in a deeper sense, decolonisation has been described as the process of freeing minds from ideologies entrenched during periods of colonisation (Goldberg, 1986; Barongo-Muweke, 2016).

As Tade Akin Aina (2010), a former professor of sociology at the University of Lagos, puts it:

"For most nations of Africa in particular, given the histories of slavery, colonization, apartheid, and inequitable economic development - often interpreted by some as expressions of collective racial and/or cultural inferiority - genuine intellec- 
tual self-determination (not to be confused with intellectual isolation or 'intellectual autarky') is a political, economic, and cultural imperative" (p. 23 f.).

Lebakeng, Phalane and Dalindjebo (2006) add on the point of contextualisation of knowledge:

"From the perspective of the sociology of indigenous knowledge, the assumptions which constructed Western thought, literature and traditions are not universal but are derived from specific and discreet Western experiences prescribed by specific historical levels of economic and industrial development. Implicit in this perspective is that standards are not universal but contextual" ( $p .74)$.

The implications of the above are that knowledge democracy and the narrowing of inequalities in academic knowledge production growing from intellectual self-determination are important issues to be considered when talking about decolonisation. These issues came to the boil in South Africa in 2015, where universities, as knowledge producers, became the focus of the decolonisation debate: students and staff members called for the decolonisation of the curricula and an end to Western dominated knowledge systems that fail to represent the diverse knowledge systems in the world (Hall \& Tandon, 2017; Heleta, 2016; Molefe, 2016).

Decolonisation in the context of higher education, therefore, not only refers to processes of gaining institutional and political independence, but also to the imperative of intellectual and academic self-determination and the contextualisation of knowledge, research, teaching and learning.

\section{CERM-ESA's approach to decolonisation}

CERM-ESA's approach is premised on the belief that collaborative partnerships in a North-South context require joint responsibility in terms of consciousness of the psychosocial and experiencebased inequalities rooted in the history of colonisation. Issues of consciousness are seen as both enablers and barriers to the process of decolonisation. CERM-ESA activities focus on methods and approaches that are rooted in and regarded most appropriate for the African context. In doing so, they aim at overcoming ideological barriers by promoting genuine and equal partnerships with mutually negotiated criteria as to whose education in whose interest (Brock-Utne, 2000) is at stake.

\section{The management level}

The conception phase of CERM-ESA started in early 2014 under the auspices of the German partner institution (University of Oldenburg), but also included long standing formal partner universities in South Africa and Tanzania. Input was also provided by individuals from the Uganda Management Institute.

On the level of the overall funding scheme of the African Excellence programme, DAAD recognised the need for the partners to meet and prepare the proposal together and thus, provided funds for a preparatory workshop - certainly not the standard route but needed in order to start the dialogue and conceptualise the project together. After initial discussions, which helped define the geographical scope of the project, namely East and South Africa, Moi University was identified as host institution for the Centre. As noted above, many of the individuals representing the partner institutions had prior long-standing relationships that facilitated a primary level of trust. However, facilitating mutual understandings was not always an easy task and often much time and a wide range of arguments and differing perspectives were required to make progress. It can now be seen that this period of finding each other was an important first step in terms of decolonising the project, something which probably was not explicitly in the minds of the participants at the time, but which is clear in retrospect.

Once the funding had been secured for the project later in 2014, a steering committee was set up consisting of representatives of all partner universities and the way forward became its major task. The advertising of master's and doctoral level scholarships and the process of interviewing applicants from the four participating African countries was done by the steering committee. During the interview process, where all steering committee members including a representative of the donor agency were present, but with only one vote per university, varying interviewer worldviews became apparent. Examples of such worldview discrepancies included certain levels of insensitivity by some from the North about the demands of cultural and religious affiliation in Africa, and the acceptance of ethnicity implicit in some of the statements made by certain members of the South. Discussions around understandings of sensitive perspectives such as these was another important step in terms of decolonising the project, with learning taking place on all sides.

All partners taking responsibility to select the best students to ensure fairness in the process has been aimed for ever since. The CERM-ESA leadership came to an understanding that in order to overcome one of the colonial heritages of the divide-and-rule practice - the oftentimes thinking in ethnic lines and opportunity hoarding for members of the own ethnic community - needs to be met with the multiperspectivity of an international selection committee. Discrimination on any kind of basis is not unique to any one of our institutions but can be found in all of them in different disguises on structural, institutional and interpersonal levels. Evidence that these tendencies exist are manifold. A Kenyan scholarship holder expressed his gratitude for the presence of CERM-ESA international representatives during the selection process by saying "I would never have had a chance to win the scholarship if you hadn't been there" - due to his belonging to the wrong ethnic group.

Needs assessments were conceptualised and carried out together in all African partner institutions in order to establish the most pressing demands for capacity building among academic and management staff. The project coordinators at Moi University, Nelson Mandela University and University of Oldenburg set up weekly skype meetings in order to discuss the ongoing activities, finances, public relations etc., starting to find their way through the management of CERM-ESA together. An international CERM-ESA advisory board was established in 2015 consisting of high profile experts in education research and management from Africa and Europe with the European members having extensive experience with education in Africa.

The cooperation agreement that was set up between the partner universities to regulate CERM-ESA activities started an internal discussion on an institutional level and challenged the project to fit into each of the partner institutions' internationalisation strategies. Winning the support of university leaderships for CERM-ESA and convincing them was an important task for the project leadership. 
The activities level

Scholarships: The process of awarding eight scholarships in a first round in 2016 allowed the steering committee to frame an academic programme for lecturers and successful students. A supervision support programme for academics in the participating universities was also developed and run as a blended short learning programme ${ }^{1}$ with 35 participants from all partner universities. In this phase, the development of the academic programme fell largely to the Nelson Mandela University, with some inputs from the German and other African institutions. One of the tasks required by the academics was for them to work in small groups (two or three) to develop a research project that could be undertaken at master's level. They were also asked to try to include an approach that would provide an Africanising or decolonising aspect of the research.

Co-supervisors from different countries: The academics who developed the eight projects which were chosen by the scholarship holders became the supervisors and co-supervisors of the students. All of the eight master's students had one supervisor and two co-supervisors from different countries, with one of the three being considered as an "emerging" supervisor on a developmental track. In this way, a total of 21 academics were engaged in the supervision process, something which could be described as cooperative and developmental. The first four doctoral scholarship students from each of the participating countries also had supervisors from an African country other than their own. One of the important components in the co-supervision process for students and staff was the international exchange and exposure to other research and teaching environments. These exchange activities took place mainly between East and South Africa.

From a North-South to a South-South perspective: During the interim, Moi University senate approved a CERM-ESA developed research master's degree of their own taking in the first cohort of 13 students in 2017. This degree was mainly the output of Moi University staff with suggestions from their peers in the other participating universities. New cohorts of master's students have been registered at Moi University (eight additional doctoral students were still shared between the institutions equally). Academics from the different universities, where appropriate, were included as external examiners and co-facilitators. These processes provided a decolonising dynamic in that the North-South power dynamic that usually pre-dominates programmes funded from the North was disrupted.

Locally relevant topics and indigenous methodologies: The topics and methodologies of the research projects also reflect a shift towards decolonisation in that they all had African perspectives to a greater or lesser extent. For instance, participatory and arts-based methodologies that had been tried and developed in South Africa have been applied and adapted for East African contexts. An investigation of indigenous knowledge in the school curriculum in South Africa and Kenya using a bespoke imbizo/ baraza methodology took up the topic of indigenous methodologies using techniques rooted in the context where the data was generated. Other examples of CERM-ESA student research projects can be found on our website (www.cermesa.uol.de). CERMESA also recognized the need to include teaching sessions on indigenous methodologies/knowledge and decolonisation in its activities such as its annual Research Schools and conferences.
The academic and supervision support programmes have been replicated over four years since 2015 and have focussed on African experiences and contexts. The project has also run leadership and management programmes within the consortium and has facilitated attendance of academic staff and researchers in international conferences, and provided sabbatical and other exchange opportunities for staff and students. ${ }^{2}$

Continuation of funding for CERM-ESA for another five years until 2023 attests to the fact that the project has attained what it set out to do. More explicit recognition, which we attribute to the decolonising guiding principle used in our approach, is reflected by the fact that CERM-ESA has been tasked by the $\mathrm{DAAD}$ to take the teaching and learning aspects of the project that have been developed over the past four years to the other DAAD sponsored African-German centres of Excellence. ${ }^{3}$

Internal and external drivers of the CERM-ESA academic project have resulted in the extension of our scope to outreach in other educational activities of South and East Africa. One such activity is an international research project on the school curricula in Kenya, Uganda, Tanzania and South Africa, which was launched in February 2019. This research activity led by the CERM-ESA steering committee together with members of the Kenyan Ministry of Education, the Kenya Institute of Curriculum Development and the Teachers Service Commission of Kenya has been enabled by additional DAAD funding between 2019 and 2023. The research focuses on the explicit and implicit calls for critical thinking, creativity and problem solving as well as other core competences at all levels in education. Similarly, CERM-ESA together with the partners mentioned above is in the process of developing professional teacher development programmes on these educational priorities in East African school education using a cascade model for its implementation. A first in-service training workshop for master trainers is planned for October 2019. These professional teacher development programmes focus on teaching competence based curricula. The conceptualisation and implementation process will include stakeholders on all levels - from policy makers to teachers, principals, education officers and early learning educators - which CERM-ESA regards as one of its decolonising strategies.

\section{Lessons learnt}

Using decolonisation as a guiding principle for CERM-ESA's activities in teaching, research and capacity building requires constant reflection on what we do and how things are done. North-South development discourse is often patronising and, as such, mitigates against making space for critical dialogue around issues of power and social justice. Recognising this fact ties in well with an interesting debate on ethical guidelines for university partnerships that have been developed in Canada by the Canadian Council for International Cooperation (Shultz, 2013). Simple things like the question of access to information (are all project documents available in English?) and creating ownership of the common objectives of the project call for transparency and patience on all sides. Awareness of the partners' interests, institutional barriers and the power relations at play require willingness to truly engage with one another and show tolerance of ambiguity. Flexible frameworks and approaches and the waiving of fixed and pre-defined output goals is imperative if power is to be shared equally to define and conceptualise programmes and activities in North-South contexts. Equally, students and staff in the North need to be sensitised about 
(post-)colonialism and approaches to decolonisation, e.g. through the integration of these topics into study programmes. CERMESA has been able to open some creative space for methodologies and approaches that are responsive to local demands and diversities in the past years. However, we do not consider decolonisation as an end-goal, but rather as a guideline for our project to consciously deal with the colonising and decolonising power dynamics at play in our personal, academic and institutional relations. Where this can be realised, activities change: research frameworks, paradigms, methodologies and standards shift from the North to the South making space for contextualisation and relevance for the African contexts we work in.

\section{Notes}

1 The 'Research Supervision and Support' programme was based on the NUFFIC (Dutch organisation for internationalisation in education) open-source programme Strengthening Postgraduate Education.

2 For more information and CERM-ESA's newsletter featuring the most important activities, see www.cermesa.uol.de

3 The Capacity Building Programme for Supervisors and Lecturers (CABLES) took place in August 2018 for the South African and Namibian Centres of African Excellence (Port Elizabeth), in November for the East African Centres of African Excellence (Zanzibar) and will take place for the West African Centres of African Excellence in October 2019 (Accra).

\section{References}

Addo, P. K. (2010). The contribution of higher education in national development. Access on 03.04.2019 http://dspace.knust.edu.gh/bitstream/123456789/1128/1/ Paul\%20Addo\% 20IJEL\%202-1.pdf

African Excellence: Fachzentren. (n.d.). Access on 03.04.2019 http://www.african-excellence.de/home/

African Union Commission (2016). Continental education strategy for Africa 20162025. CESA 16-25. Addis-Ababa: AUC.

Aina, T. A. (2010). Beyond reforms: The politics of higher education transformation in Africa. African Studies Review, 53(1), 21-40.

Barongo-Muweke, N. (2016). Decolonizing education: Towards reconstructing a theory of citizenship education for postcolonial Africa. Wiesbaden: Springer VS.

Brock-Utne, B. (2000). Whose education for all? Recolonization of the African mind. New York: Falmer Press.

Brock-Utne, B. (2017). Decolonisation of knowledge in the African university. In Cross, M. (Ed.), Knowledge and Change in African Universities. Rotterdam: Sense Publishers, 161-181.

Goldberg, M. (1986). Decolonisation and Political Socialisation with Reference to West Africa. The Journal of Modern African Studies, 24(4), 663-677.

Hall, B. L. \& Tandon, R. (2017). Decolonization of knowledge, epistemicide, participatory research and higher education. Research for All, 1(1), 6-19.

Heleta, S. (2016). Decolonisation of higher education: Dismantling epistemic violence and Eurocentrism in South Africa. Transformation in Higher Education, 1(1), $1-8$.

Horowitz, D. (1970). Attitudes of British Conservatives towards decolonization in Africa. African Affairs, 69(274), 9-26.
Lebakeng, J. T., Phalane, M. M., Dalindjebo, N. (2006). Epistemicide, institutional cultures and the imperative for the Africanisation of universities in South Africa. Alternation, 13(1), 70-87.

Mbembe, J. A. (2016). Decolonizing the university: New directions. Arts and Humanities in Higher Education, 15(1), 29-45.

Molefe, T. O. (2016). Oppression Must Fall: South Africa's Revolution in Theory. World Policy Journal, 33(1), 30-37.

Möllendorff, M. v., Kurgat, S., \& Speck, K. (2017). East and South African-German Centre of Excellence for Educational Research Methodologies and Management (CERM-ESA). A case for internationalisation and higher education engagement. Educational Research for Social Change, 6(1), 93-99.

Odora Hoppers, C. A. (Ed.). (2002). Indigenous Knowledge and the Integration of Knowledge Systems: Towards a philosophy of articulation. Claremont, CA: New Africa Books.

Ordorika, I. (2017). Knowledge and Change in Contemporary Postcolonial Universities. In Cross, M. (Ed.), Knowledge and Change in African Universities: Volume 1Current Debates. Rotterdam: Sense Publishers, vii-xvii.

Shultz, L. (2013). Exploring partnership principles and ethical guidelines for internationalizing post-secondary education. In Hébert, Y. \& Abdi, A. A. (Eds.), Critical perspectives on international education. Rotterdam: Sense Publishers, 75-87.

\section{Prof. Dr. Jonah Nyaga Kindiki}

is a Professor of International Education and Policy at the School of Education of Moi University in Eldoret, Kenya. He is the former Kenyan Project Leader for the East and South African-German Centre of Excellence in Educational Research Methodologies and Management (CERM-ESA). His research interests include international education, policy and development, and the link of theory and practice in implementation of education policies in Sub-Sahara Africa.

\section{Prof. Dr. Karsten Speck}

is one of the two Project Leaders for the East and South African-German Centre of Excellence in Educational Research Methodologies and Management (CERM-ESA) at the Carl von Ossietzky University of Oldenburg in Germany. He is a professor of research methododologies in education and educational sciences at the Institute for Education. His research interests include teacher and university education as well as civic engagement.

\section{Malve von Möllendorff}

is the project coordinator of the East and South African-German Centre of Excellence for Educational Research Methodologies and Management (CERM-ESA) at the Carl von Ossietzky University of Oldenburg. She has coordinated various North-South cooperation projects in education and sustainability sciences and has been involved in research projects on peer learning, HIV and AIDS in education, diversity and non-discriminatory education.

\section{Prof. Dr. Paul Webb}

is Emeritus professor of science education at the Nelson Mandela Metropolitan University in Port Elizabeth, South Africa and is the South African Project Leader for the East and South African-German Centre of Excellence in Educational Research Methodologies and Management (CERM-ESA). His research interests include the promotion of scientific literacy, understanding alternative worldviews, language issues in teaching and learning, and the development of thinking skills. 